\title{
6 \\ Life, death and journeys of regeneration in Saribas Iban funerary rituals
}

\author{
Clifford Sather
}

\section{Introduction}

My concern in this chapter is with what Penelope Graham (1991: 217), in her study of 'paths of life' in eastern Flores, has called 'regeneration'that is, the sociological process by which a younger generation in society accedes to the social and ritual roles previously performed by members of the preceding generation. Here, I focus, in particular, on Saribas Iban funerary rituals and the way in which these rituals represent societal regeneration through imagery of paths and journeys and by an analogic association of societal regeneration with the seasonal renewal of botanic life, particularly the life of cultivated crops.

The Iban are the single most populous 'Dayak' group in western Borneo. Although they trace their origins to the Kapuas River Basin of presentday Indonesian Borneo, the majority of Iban today inhabit the Malaysian state of Sarawak, where, in 2010, they numbered just over 700,000 (Department of Statistics Malaysia 2012; Sather 2004). Iban death rituals differ notably from one region of Sarawak to another and are everywhere now rapidly changing. The material presented in this chapter derives primarily from fieldwork carried out intermittently from 1977 to the 
present in Iban communities along the Paku and Rimbas tributaries of the main Saribas River, which, together with the smaller Krian and Awik rivers, form the main arteries of Iban settlement in what is now the Betong Division of western Sarawak. ${ }^{1}$

\section{Life and death as journeys of renewal}

Both life and death are described by the Iban as 'ways' or 'journeys' (jalai), each of which is thought to unfold in a different cosmic realm: the 'way' or 'journey of life' (jalai idup) in what the Iban describe, literally, as 'this world' (dunya tu'); the everyday visible world inhabited by living human beings; and the 'way' or 'journey of death' (jalai mati) in Sebayan, the invisible afterworld of the dead. In Iban, the word jalai (PMP ${ }^{*}$ zalan [Blust 2013]) means not only 'path', 'way', 'road' or 'journey', but also, more abstractly, for any kind of activity, the prescribed manner in which it should be done. ${ }^{2}$ Thus, for example, jalai bumai refers not only to the act of rice farming (bumai), but also to the methods by which rice farming should be carried out. Jalai thus often has a normative connotation and inscribes a linear and/or temporal dimension to whatever activity it refers. Jalai may also refer to the 'path' one traverses in the course of a journey. Understood in this way, an Iban saying has it that 'the path of life is as narrow as the pith of a palm tree that grows on the site of a former longhouse' (sekut jalai idup mesai lumut aping tembawai), while 'the path of death is as broad as two rice storage bins placed side by side' (senang jalai midang mesai tibang dua berimbai) —namely, life is perilous; death is inevitable. The journeys of life and death not only follow a circumscribed path of varying width, but each is also of limited duration. Under ordinary

1 I wish to thank the Sarawak Government for permission to carry out this work and the Universiti Sains Malaysia and the National University of Singapore for their early support. For 12 months in 1993-94, my research in Sarawak was funded by a Fulbright translation grant and, since 1991, has been carried out under the auspices of the Tun Jugah Foundation. I am especially grateful to the foundation and its founding director, Tan Sri Datuk Amar Leonard Linggi Jugah, for their unstinting support. In addition, I thank Jantan Umbat, Jim Fox and Moto Uchibori for their insightful comments on earlier drafts of this chapter.

2 Jalai is a fundamentally important concept that resonates in many areas of Iban life. Thus, for example, before a new longhouse is constructed, its site must first be measured out and ritually constituted as a jalai. This is done through a rite called ngerembang jalai (literally, 'to clear' or 'trod down a path') (Sather 1993: 108n.5). The purpose of the rite is to remove obstructions, particularly those that may be presented by the spirits displaced from the site. After its performance and the completion of the longhouse, those who come to occupy the house resume their life journeys as longhouse members with a reduced likelihood of spiritual interference. 
circumstances, sooner or later, both journeys come to an end. On the other hand, the two are connected and interdependent. Thus, the second, the journey of death, represents a continuation of the first, the journey of life, and concludes with a return of life-renewing power to this world, the place from which the first of these two journeys begins.

In this world, each person's life journey begins at birth, and ideally, before it ends, passes through three successive stages, each defined by the traveller's generational level (serak) vis-a-vis others of adjacent generations. These stages are 'child' (anak), 'parent' (apilindai) and 'grandparent' (aki') ini'). ${ }^{3}$ In everyday social interactions, persons are constantly reminded of their generational positioning relative to others by the universal use of generational teknonyms. To live a complete lifespan, passing through all three of these stages, is, the Iban say, to be gayu ('long-lived') — a condition frequently wished for in Iban prayers and blessing formulas.

On the other hand, those who live beyond what normally constitutes a complete lifespan are treated differently at death from others. Persons who live to extreme old age are thought to begin their transition into death even while they are still alive. Thus, their 'soul' (semengat) — the vital component of each person's living self-is said to depart from their body for long periods to spend time in Sebayan in the company of the spirits of their deceased friends and relatives, returning to this world only occasionally to re-inhabit their body. Such persons are described as being setengah antu-literally, 'half-spirits' (Sather 2003b: 180). ${ }^{4}$ The families of the rare few who live beyond a normal three-generation lifespan, and so attain the status of 'great-grandparents' (umbuh), need not observe a period of formal mourning (ulit) for them when they die. This is because they are said to have already transitioned into Sebayan, so that, when they cease to breathe, they 'do not die' (enda' mati) but, rather, are said to simply 'return home' (pulai). With the passage of a full three-generation cycle, the birth of a fourth generation of descendants is marked by the re-bestowal (ngangkatka) of the personal names (nama) that, in life, belonged to ancestors of the umbuh generation. By this time, these ancestors are assumed to have died. This practice of name inheritance

3 Serak, the term used to refer to 'generation' (for example, serak ke dulu', 'previous generation'; serak ke baru, 'younger generation'), more generally means a 'layer' or 'level' (Ensiring et al. 2016: 1504).

4 As we shall see, once a person dies, he or she is said 'to become a spirit' (nyadi antu). 
not only marks the passage of a full three-generation cycle of life, but also helps to perpetuate a memory of deceased ancestors and their this-worldly achievements. ${ }^{5}$

At the other extreme, those who die prematurely, are stillborn, aborted or die in infancy are described as anak mati lulus ('stillborn'). At death, their bodies are simply buried without ceremony. Although it is said that infants are born with a soul, until their first tooth has erupted, their soul lacks a firm point of anchorage inside the body. Hence, a newborn's connection to life is precarious. Like the elderly at the opposite end of life's journey, they have only a weak attachment to this world. ${ }^{6}$ Following death, the souls of the anak mati lulus are said to journey to a special place within Sebayan called Kendi Aji, where the road entering the afterworld branches into multiple paths (Sather 1978: 329-30). Here, the anak mati lulus are thought to continually interrogate newly arriving souls to find the parents from whom they were separated at birth. Similarly, the souls of those who die untimely or violent deaths — such as by falling from a height (mati labuh), drowning (mati lemas), taking their own lives (mati makai tubai) or, in the case of a woman, dying in childbirth (mati beranak)—also journey to separate regions within Sebayan. Here, like the anak mati lulus, they live lives removed from the ordinary dead and, in this state, are believed to be beyond ritual recall. Consequently, they are no longer able to involve themselves in the lives of the living and so make no further contribution to the process of this-worldly regeneration.

Every person's 'soul' (semengat) at the time of death is said to take permanent leave of the body (tubuh). Escorted by the soul of a female 'soul guide' (tukang sabak), this now disembodied soul is taken on a ritual journey to Sebayan. Here, it eventually takes up its proper place as determined by the circumstances of its death. In Sebayan, the constant arrival of souls is said

5 Nama ('name') in Iban also means 'reputation'. Those whose names are re-bestowed are typically men and women of renown, former leaders and persons of exemplary character. Conversely, the names of those who were known in life as troublemakers or adulterers or who died prematurely or as a result of a sudden or violent death should not be passed on to the young lest they inherent these traits or suffer a similar fate. Names, I was told, cannot be bestowed earlier, while the name-bearer and the recipient of the name are both alive, because of the rules of name avoidance that apply among living kin. This practice of re-bestowing names is clearly apparent in Iban genealogies and, in the Paku region where I did most of my fieldwork, can be traced back in local genealogies over at least 12 generations.

6 For this reason, when treating small infants, shamans re-insert their recovered souls not into the infant's body, but usually into that of the mother. On the other hand, if a family provides a substitute for the absent tooth—either a shell armlet (rangki') or an object made of iron (besi) — they may, in burying this object with the infant's body, perform the usual death rites observed for a young child. 
to continually replenish the numbers residing there. With the departure of the soul from the body, the Iban say that the deceased 'becomes a spirit' (nyadi antu). The term 'spirit' (antu) has two meanings in this context. In the first, it refers to the deceased's now inanimate corpse (bangkai). Thus, at the time of burial, transporting the corpse to the cemetery is described as nganjung antu (literally, 'to send the spirit [to the cemetery]'), while burying it is called numbak antu (literally, 'to bury the spirit'). Upon burial, the corpse rapidly decomposes. In the process, it returns to the material from which it was created-namely, 'earth' (tanah). In its second meaning, antu refers to what is now thought to be a newly emergent spirit identified with the deceased. For most persons, this spirit, after lingering for a time in this world, is also said to journey to Sebayan, where it remains in a transitional state until the conclusion of the final rite of the funerary cycle, the Gawai Antu. ${ }^{7}$

For the souls of the ordinary dead, life in Sebayan is thought to be generally similar to life in this world. In arriving there, the great majority of souls take up residence along the Mandai River of the Dead (Batang Mandai Mati). ${ }^{8}$ Here, they live in longhouses, cultivate rice and other food crops and rear families much as the living do in this world. Like life in this world, life in Sebayan is also finite. Unlike mortal life, however, it unfolds in a series of further lives, deaths and rebirths - generally seven in all. After a seventh death, the final material residue of the soul dissolves into a watery mist. This condenses, especially in the early hours of the morning, and falls to earth as 'dew' (ambun). This occurs especially at the end of the dry season, just after families have finished planting their annual rice fields. The dew is then taken up and nourishes the newly germinating rice plants. Thus, in this way, the soul stuff of the ancestors is incorporated directly into rice, which, as the staple food of the Iban, serves to sustain each new generation of human life in this world (Sather 2012: 122).

The total journey of each person's soul through life and death is thus ontologically connected. Life in this world ends in death, whereupon the soul transitions to Sebayan, where it resumes its journey, this time through a series of rebirths and deaths, ending with its final transubstantiation

$7 \quad$ As Reed Wadley (1999: 599) notes, in practical terms, when addressing prayers or making offerings, the Iban generally refer to their deceased ancestors not as 'ancestors' (aki'ini'), but either as antu (spirits) or, as I will explain later, following the Gawai Antu, as petara (gods).

8 The Mandai River has a visible counterpart in this world, an actual river: a southern tributary of the Kapuas in Kalimantan Barat, known to the Iban as the Batang Mandai Idup ('Mandai River of the Living') (Sather 2012: 123). 
and return to this world as dew, which, through the medium of rice, is re-embodied in a new generation of humans. The connection of both these journeys with the parallel cycling of life through cultivated crops is predicated on the coexistence both in this world and in Sebayan of what Penelope Graham, in reference to Flores, has called 'separate productive systems' (1991: 259). Thus, subsistence in both this world and the next similarly depends upon the cultivation and consumption of plant crops. Successful cultivation requires husbanding the generative power inherent in the seeds of these crops or their cuttings. The work of tending this material makes possible the continuous cycling of plant life from one farming season to the next. As living humans subsist on these crops, the parallel cycling of human life is therefore dependent on this same work of husbandry. For the people of Léwotala described by Graham, the living, at the time of death, ritually take back from the dead the seeds of all the vegetable food crops they consumed during their lifetime so that the total seed stock available to the living is never depleted, but remains available for each new season's planting. In this way, the living receive from their ancestors the generative potential inherent in their cultivated crops. During Iban funerary rituals, a similar transfer occurs, but in the opposite direction. Here, the surviving family shares its stock of seeds and cuttings with the dead, so that the latter are able to use this material to establish themselves as self-sufficient cultivators in Sebayan. Hence, the ancestors are the ones who, for the Iban, are dependent upon the living. While expressed differently, the outcome is the same: the living and the dead, between them, by cultivating crops, each in their own realm, promote a mutually dependent cycling of life through both plants and humans.

\section{Funerary rituals and societal regeneration}

Funerary rituals have been a subject of special interest to anthropologists in Borneo ever since the publication in 1907 of Robert Hertz's classic essay 'Contribution à une étude sur la représentation collective de la mort' ('A contribution to the study of the collective representation of death') (Hertz 1960). In Hertz's essay, as in this chapter, the central question concerns how the ritual treatment of the dead relates to the temporal renewal of society. In this connection, Hertz argued that death, especially in societies of the Malayo-Indonesian archipelago, is seen as a transformative process, rather than a single momentary event. In consequence, funerary rites typically extend over a protracted period 
and are divided into stages marking distinct points of transition within this process. Hertz was particularly struck by the parallels he found in Borneo between the treatment of the corpse of the dead and beliefs relating to the fate of the deceased's soul and to the ritual condition of the mourners. In explaining these parallels, he drew attention to the fact that the deceased is not only a biological individual but also a social being. Hence, death not only extinguishes 'the visible bodily life of an individual; it also destroys the social being grafted upon the physical individual' (Hertz 1960: 77).

Hence, Hertz argued, funerary rites are always double, for there are two tasks that must be achieved. On the one hand, the individual must be 'disaggregated' from the collectivity, both socially and in regard to his or her bodily remains, and, on the other hand, society itself must be 'reinstalled', by which Hertz meant that the roles once played by the deceased must be allocated to others. In the course of this reallocation, the dead are believed to attain a permanent place in the afterworld, as the social void left by their death in this world is filled by others, while the mourners, in a parallel way and following a period of seclusion, rejoin the collectivity and resume their everyday social lives. These two phases of the mortuary process - disaggregation and reinstallation-are thus linked both with beliefs about the fate of the soul and with ideas concerning the ritual condition of the mourners.

It takes time, Hertz argued, for the collectivity to readjust to the death of one of its members. This fact is expressed in notions that the period immediately after death is one of special danger during which the departed soul is believed to be potentially malevolent. Paralleling this idea, the mourners, too, are in a perilous state and must be isolated for a time from society. Following a transitional interval of readjustment, the final stage of the funerary process asserts the ultimate triumph of society over physical death. This is represented by a termination of mourning restrictions and, in a parallel way, a belief that the deceased's soul is now fully incorporated in the society of the dead (Hertz 1960: 86).

Hertz's essay was a groundbreaking contribution, particularly to an understanding of how the structure of funerary rituals relates to the temporal processes by which a society regenerates itself over time. But for all his insight, Hertz never fully escaped a narrow conception of 'bodily life', and so failed to see that interposed between society and the physical body are often complex conceptions of the self that may equally well 
shape social constructions of death. He also failed to see the way in which the particular circumstances of an individual's death may bear upon his or her role in societal regeneration. Unlike the Ngaju, whose double funerals and protracted secondary treatment of the dead strongly influenced Hertz's analysis, the Iban, like a number of other Borneo peoples, while also performing complex and protracted funerary rituals, do not, under ordinary circumstances, practice secondary treatment or reburial of the dead. ${ }^{9}$ Instead, the body, upon death, is buried almost at once and plays no further part in the rituals that comprise the Saribas funerary cycle. Instead, the complexity of this cycle is related to a view of the self as an internally differentiated entity, comprising components that participate in the ontological conditions of 'life' and 'death' in different ways. Consequently, death, when it occurs, is perceived, not as a single event, but as a complex process involving the disaggregation and independent transformation of these components. The primary components involved in this process are the 'soul' or semengat, the 'plant-image' or bungai and the 'spirit' or antu. Each of these components is the focus of a separate ritual and, together, these rituals make up, in sequential order, the main rites of the Saribas Iban funerary cycle.

\section{Life, death and the differentiated self}

For the Iban, death is characterised not by a total annihilation of the self, but by a gradual disassociation and transformation of its constituent elements. The beginning of this process is signalled by the cessation of breathing (abis seput). Some say that the 'breath' (seput or nyawa), as a source of this-worldly life, inhabits the veins, together with the blood (Sather 2001: 50-55). At death, these and other elements making up the body $(t u b u h)$, including the bones and flesh, are said to begin to decompose and so return to 'earth' (tanah), the medium from which they were created. As earth, these elements are said to be repeatedly remoulded and reforged by the Iban creator god, Selempandai, who, as a blacksmith, fashions each human body at his forge at the time of conception (Sather 2001: 105-8). In this way, new bodies are continually refashioned from the elements that formerly made up the bodies of the dead, as the earth from which they were made is constantly recycled by Selempandi.

9 There is, however, a significant exception—ngelumbung or 'entombment'-described later in this chapter. 
The 'soul' (semengat), on the other hand, as a second component of the self, is 'not extinguished' (enda' abis) when breathing ceases, but, rather, in contrast to the body, 'remains alive' (bedau idup). At death, however, it takes permanent leave of the body that, until then, served as its 'container' (karung). ${ }^{10}$ Indeed, shamans say that a person's semengat leaves the body and begins its journey three days before breathing stops. On the fourth day, as the soul crosses over Lanjan Ridge, well inside Sebayan, at the point where shamans can no longer recover it and bring it back to this world, breathing ceases, the blood stops circulating and the body begins to decompose (Sather 2001: 55-58). ${ }^{11}$

In addition to the body and soul, each living person is also composed of a 'plant-image' (bungai or bunga). ${ }^{12}$ This image is said to exist separately from the body in an unseen region of the cosmos closely associated with the shamanic god Menjaya. Here, some say, it is tended by the spiritcompanions of living shamans. ${ }^{13}$ Some identify these companions with the spirits of deceased shamans who once lived as humans. The bungai appears in the form of a plant-most often likened to a bamboo or banana plant. Like the latter, it typically 'grows in a clump' (bepumpun) from a common rootstock called the pun or pugu' bungai. Each clump is said to represent a single bilik-family and each bungai, an individual family member. These clumps grow in gardens, each of which, some say, represents a longhouse community. Thus, these gardens are sometimes described as rumah semengat ('longhouses of the souls'). The condition of the plants growing in them reflects the collective vitality of all who live in the same longhouse. Menjaya, by inspecting these gardens, is therefore able to monitor the wellbeing of the various human communities present in this world. The bungai is thus, at once, both an individual and a socially encompassing image. Unlike the semengat, a person's bungai 'dies' when

10 Some Iban claim that humans have multiple souls and describe this primary soul as the "body soul' (semengat tubuh) (for a detailed discussion, see Sather 2001: 51 ff.).

11 Iban shamans use crystals (batu karas) as a diagnostic tool to spy out their patients' semengat, which may be revealed in this way as having strayed prematurely into Sebayan (Sather 2001: 130-32, 274-77).

12 The term bunga or bungai literally means 'flower'. Ayu is sometimes used as an alternative term to refer to essentially the same plant image, but in a context where it often has a somewhat different meaning (see Sather 2001: 58-65). In general, the term bungai tends to be used-as in the beserara' bungai-in connection with mortality, while ayu is more frequently associated with longevity (gayu), healthful vigour and reproduction. Thus, the plants tended in the upper world by the spirits of ancestral shamans are, some say, more fittingly described as ayu.

13 As Uchibori (1978: 20) notes, conceptions of the bungai are less well articulated than most other aspects of the self. Among the Layar Iban, he writes, the bungai is believed to grow not in another cosmic realm, but inside the family apartment, at the foot of one of the posts supporting the drying rack above the family's cooking hearth. 
breathing ceases and the soul departs from the body. In this sense, the bungai mirrors each person's this-worldly state of health and mortality. When a child is born into a family, a new bungai is said to sprout from the family's pugu'bungai. In good health, this bungai grows and flourishes like a healthy young plant, while in ill health or old age, it yellows and withers (nyadi layu'), and in death, it dies (mati) and falls to the earth (gugur). As an encompassing life image, the bungai reflects the condition of both the body and the soul. If, for example, the soul is absent from the body, a person 'feels withered' (berasai nyadi layu'). Similarly, if the bungai is ill, scorched by heat or overgrown with weeds, the body and soul are said to suffer. At death, however, unless this death results in the extinction (punas) of the entire family, the family's rootstock lives on, capable of generating new bungai to replace those who have died (Sather 2001: 61; 2003b: 207). In this way, the bungai symbolises not only an individual's vitality and mortal life, but also family continuity and the capacity of society for renewal.

Finally, with the cessation of breathing, the departure of the soul and the death of the bungai, the deceased is said 'to become a spirit' (nyadi antu). This spirit, as we have noted, is identified at first with both the deceased's corpse and what is described as a newly emergent spirit. At first, as a spirit, the deceased is reluctant to leave the society of the living. Almost at once, however, it begins to lose its human attributes, appearing as an increasingly frightening spectre. Thus, its lingering presence is perceived in largely negative terms as a threat to the living. For the first three nights after burial, during a period called pana, a bonfire (tungkun api) is built not far from the longhouse and kept burning throughout the night. Here, a simple shelter is erected, where, during each of the three nights of pana, the deceased's antu gathers to warm itself. In addition, by the light of the fire, it sees itself as it now appears, no longer a mortal human being, but a spectre, and so realises that it no longer has a place among the living. Thus, the deceased's spirit, at the end of pana, quits this world and, like the soul, journeys to Sebayan. Once established there, it is gradually transformed into a benevolent antu Sebayan (literally, a 'spirit of the afterworld'). Here, in Sebayan, an individual's antu, rather than the now disembodied semengat, becomes the principal component of the self that represents the deceased in his or her interactions with the living. While in this world the embodied soul functioned as an individual's primary source of agency — what Raymond Firth (1967: 342) calls, in reference to Tikopia, an individual's 'vital personality' - in death, this personality 
is replaced with the deceased's spirit, or antu Sebayan, representing what Firth calls the 'survival personality', or what I would term his or her 'post-mortal self', which functions, in the Iban case, as its 'afterworld counterpart'. ${ }^{14}$ At the culmination of the funerary cycle, the spirits of the most recent cohort of longhouse dead are recalled to this world, where, as we shall see, they undergo a final transformation, shedding the last traces of their corpse-like materiality, and so become deified ancestral spirits. From what is now a realm of their own, separate from the living world, they join the preceding generations of ancestral dead to play a role in the lives of their living descendants analogous to, and ultimately merging with, that of the gods. ${ }^{15}$

The journey of each person through life and death is not only protracted, but also involves multiple transformations. Some of these transformations occur in the course of a person's journey through this world, while others are a result of death or occur in the final return of life-renewing potency back to this world. In addition, shaping these journeys are what James J. Fox (1987: 523) has described as elements of a common Austronesian conceptual heritage-specifically, 'a belief in the immanence of life and in the interdependence of life and death'. As life depends on death, 'the ancestral dead or specific deceased persons, whose lives were marked by notable attainments, [are thereby] regarded as capable of bestowing life-giving potency' (Fox 1987: 525). Hence, the ancestral dead-most notably, those who enjoyed long and successful lives in this world-play an important part in the regeneration of life, and the achievements they attained while journeying through this world help define the conditions they and others will experience during their own subsequent journey through Sebayan.

14 In Tikopia, the two are terminologically distinct (see Firth 1967: 337). The 'soul'-that is, the 'life force' or 'vital personality' that animates a living person-is called the mauri or ora. At death, a person's mauri ceases to exist and is replaced with the atua, the deceased's 'spirit', representing what I would call his or her postmortal self.

15 Although the Iban terms antu and petara are often defined, respectively, as 'spirit' and 'god', the Iban in fact do not make a clear distinction between the two, often using both terms interchangeably. Generally, however, once the spirits of the dead have been recalled during the Gawai Antu, they are thereafter addressed in prayers as petara or, more specifically, in couplet form as petara akilpetara ini' (literally, 'grandfather god/grandmother god'). 


\section{The immanence of life and the interpenetration of life and death}

While I have stressed here the Iban notion that life and death unfold in different cosmic realms, it is important to add that this notion coexists with another that asserts that the living and the dead live in close proximity and that, if our eyes were not covered by a thin, translucent membrane, we would be able to see the dead and share directly in their experiences (Sather 2001: 111-15). Moreover, the conditions that define life and death are thought to interpenetrate. Thus, while still alive, an individual may experience aspects of death, such as soul loss (semengat lelung) or a withering of his or her plant-image (bungai layu) (Sather 2003b: 179-82). Thus, at some level, the separation of the living from the dead is a matter more of visual perception than of spatial distance. Although the living may no longer be able to see those who have died, they and the dead can still communicate with one another. A person wishing to make contact with a deceased parent may, for example, wrap himself in a ritual ikat cloth before going to sleep at night. In so doing, he 'makes himself visible' (ulih peda') to the dead, so that they may, in response, appear and converse with him in his dreams (mimpi).

In fact, some persons say that the dead do not really depart from this world at all, but that Sebayan is, in actuality, an inverted realm that exists beneath the floor of the longhouse (see Sather 1993: 111, n.42). Thus, at night, people say, the spirits of the dead may sometimes be heard as they go about their daily affairs - night in this world being day in Sebayan. For this reason, too, the living, before eating meals, often drop small bits of food through the floor of the longhouse as a share for the dead. Similarly, just before the corpse is placed inside a coffin prior to being carried to the cemetery, a final meal is served to the deceased, after which the plate and cup that were used are broken-broken objects being whole in Sebayan - and these, too, are dropped beneath the longhouse floor. Similarly, on ceremonial occasions, when asked by a host to drink rice wine, it is customary for the drinker to first pronounce a formula, 'Give the ancestors drink' (meri' petara ngirup), and then to pour a small amount of wine through the floor slats, before drinking himself (Wadley 1999: 599). 


\section{The Saribas Iban funerary cycle}

For the Saribas Iban, death rituals, at least through the 1970s, comprised a tripartite series in which each major ritual was performed by a different ritual specialist. The first of these rituals, called nyenggai antu or rabat, focuses on the deceased's 'soul' and is conducted by a female soul guide (tukang sabak). The second, the beserara' bungai, focuses on the deceased's 'plant-image' and is performed by a shaman (manang), while the third, the Gawai Antu, focuses on the deceased's 'spirit' and is conducted by a company of priest bards (lemambang).

\section{The soul's journey to Sebayan: Rabat}

The moment a dying person stops breathing, a rice-pounding pestle (alu) and mortar (lesung) are placed across the entrances at each end of the longhouse to prevent the spirits of the dead from entering. Inside the family apartment, the body is bathed and dressed, while on the gallery, a rectangular enclosure called the sapat is constructed of ritual cloth. After being bathed, the corpse is placed on a finely woven mat, carried from the apartment and placed inside the sapat.

Inside the apartment, over the next few days, the family makes a collection of personal belongings, including necessities for the deceased's use in the afterworld. Together, these things are called baya' and, at burial, they are either interred with the body or placed on top of the grave. In addition, there is a special category of objects called the baya' pandang ('display baya") that are not taken to the cemetery, but instead are retained by the family and are first 'opened' (diketas) during ngetas ulit, a small rite that marks the end of mourning, and then put away again until they are brought out for display during the Gawai Antu.

After the body has been placed inside the sapat, a date is set and preparations begin for rabat, a night-long vigil that immediately precedes burial. Four major things take place during rabat: first, an announcement is made of the cause of death; second, the deceased's life history is recounted, and, related to this, third, the longhouse elders specify the duration of mourning (ulit) and announce the amount of the deceased's adat pemati. Adat pemati, narrowly defined, refers to the size of fines (described as adat) to be levied should the rules of mourning be violated. More significantly, however, it stipulates the type of garung basket that will be woven for the deceased during Gawai Antu. The amount of adat pemati is set beforehand by the deceased's immediate kindred and, after 
its announcement, it must be discussed and affirmed by the vigil guests. For the Saribas Iban, the amount is a matter of utmost importance because, in this highly competitive society, it is taken to be a measure of each individual's lifetime accomplishments. Fourth, to conclude rabat, a soul guide sings the $s a b a k,{ }^{16}$ a travel narrative in which her soul escorts the soul of the deceased on its journey to Sebayan.

The tukang sabak typically begins to sing the sabak well after dark and continues until an hour or so before daybreak the following morning. ${ }^{17}$ In the sabak, the soul's journey is related chiefly from the point of view of the tukang sabak's soul, with dialogue, conversational exchanges and descriptions of boundary crossings (Sather 2003b: 187-91; Sutlive 2012)..$^{18}$ In the opening stanzas, the deceased is addressed directly and informed that his or her presence in the living world is now at an end. This opening is set inside the longhouse interior. It begins on the gallery, inside the sapat, where the soul guide sits beside the deceased's body as she sings, and from there the narrative moves across the tempuan passageway and into the family apartment. Here, each important feature of the apartment is now introduced and taken leave of, beginning usually with the family's cooking hearth (dapur). These parts of the house now appear as they do to the deceased's soul. Hence, they are personified and speak. The imagery is thus, at once, both familiar and alien. While the deceased is now able to see beneath visible appearances and so converses directly with the semengat of the objects of which he is taking leave, he himself, being now disembodied, can no longer touch or feel them.

16 Sabak is the root form of the active verb nyabak, meaning, literally, 'to weep', 'cry' or 'lament'.

17 Since my initial fieldwork in the 1970s, many Christian families have replaced the singing of the sabak with a simple Christian service. Some have also dispensed with the sapat.

18 It is important to bear in mind that what is described here relates specifically to the Saribas (Saratok and Skrang) Iban. In the Rejang, the Iban funerary cycle is quite different. The Rejang Iban typically perform not one, but two, sabak. The first, called the sabak kenang, is much like the Saribas $s a b a k$ and is performed, like the latter, during the night preceding burial. The Rejang counterpart of the beserara' bungai, generally called the beserara' bungai layus, is performed much earlier than in Saribas, on the third night after death, and is the occasion, like the Saribas rabat, on which the length of mourning is fixed (Sather 2003b: 205n.21). In the Rejang, the second sabak is called the sabak lumbung or, particularly in the upper Rejang, the Gawai Lumbung. As the final rite of the funerary cycle, the sabak lumbung is performed some time after the conclusion of ulit, usually within a year or so of death. Although it is performed by a tukang sabak, and so is not a major bardic ritual like the Saribas Gawai Antu, the ancestral dead are similarly recalled to the longhouse of the living, where they are honoured and exchange goods with their human hosts, including cultivated crops (see Sutlive 2012: 4). In contrast with the Saribas and despite the ritual's name, there is no association of lumbung with the construction of a tomb to enshrine the physical remains of the dead. 
The ancestral dead, barred from entering the longhouse, gather at the bottom of the entry ladder. Leaving the family apartment, the deceased now passes along the tempuan passage and from there descends to the ground. From there, in the company of the antu Sebayan, the party journeys along the same path that the deceased's corpse will take on its way to the cemetery. Beyond this point, the surroundings they pass through become increasingly unfamiliar, until, at last, they reach the dark, gloomy frontier where Bunsu Bubut, the coucal bird goddess, makes her home. ${ }^{19}$ The party has now arrived at Titi' Rawan (the 'Bridge of Fear'), across which the deceased's soul must pass to reach Sebayan. The brave pass over easily, but for others the Titi' Rawan shrinks to the size of a small quivering pole. On reaching the other side, the party finds the grave goods (baya') left at the cemetery. The party now comes to a second barrier, the Pintu Tanah ('Earthen Door'), which only Bunsu Belut, the worm goddess, can open for them. On the other side, they pass, one after another, the areas inhabited by the souls of those who died ill-fated deaths. Close by, at a river landing, they find boats awaiting them. Using these, they journey downriver, then up the Mandai River to the landing place of the dead, where the deceased is welcomed by the spirits of his ancestors.

As soon as the sabak is finished, the deceased's body is removed from the sapat, placed in a coffin and carried to the cemetery. There, burial takes place just before dawn, while it is still daylight in Sebayan. Returning to the longhouse, the burial party and other mourners are invited into the deceased's bilik. Here an elderly woman, ideally the oldest in the community, is called upon to feed the newly widowed spouse, if the deceased was married, or, if not, the eldest surviving member of the family, the first of three balls of black rice called the asi pana. Each ball stands for one day of pana, during which time no-one may leave the house to work or travel outside. In the past, during these three days, the deceased's family remained in total seclusion. To mark its disjunctive status, during daylight hours, windows and skylights were closed, so that the apartment was kept in darkness. The family was not permitted to light a fire on its hearth and, instead, other families had to prepare special meals for them. After the last ball of asi' pana was eaten, at dawn, a chicken was sacrificed and its blood smeared on the window frames, after which the windows and skylights were reopened to introduce daylight back into

19 The plaintive call of the greater coucal or crow pheasant (Centropus sinensis), when heard in this world, is believed to signal the passage of a human soul into the afterworld. 
the apartment. Much as in the manner described by Hertz, pana reflected the family's temporary disengagement from the life of the community, while, similarly, the deceased, now neither able to return to the longhouse of the living nor yet fully installed in Sebayan, is thought to gather each night to warm itself at the tungkun api.

Pana is followed by a longer period of mourning called ulit. Ulit, literally, refers to a small container in which a few of the personal effects of the deceased were placed at the time of death, including the items of baya' pandang mentioned earlier. The lifting of ulit restrictions is marked by a small ritual called ngetas ulit (literally, 'to cut open the ulit'). In the past, a man of prowess, a warrior or seasoned traveller was often invited to open the ulit, and, even today, the ritual is often preceded by a mock headhunting raid-now frequently performed as a predawn or early morning game hunt. At its conclusion, the man invited to open the ulit shouts a war cry (mangka'ka selaing) as he approaches the longhouse or fires a shotgun into the air. Those inside respond by beating gongs, thereby breaking the silence enjoined by mourning. ${ }^{20}$ Entering the house, the performer cuts the fastenings binding the ulit and removes the personal effects from inside. After this, he cuts a small bit of hair from each member of the deceased's family and waves a cockerel over them, thereby releasing them from mourning restrictions. ${ }^{21}$

\section{Severing the plant-image: Beserara' bungai}

The second major ritual of the Saribas funerary cycle, the beserara' bungai (or bunga), is usually performed during the night immediately following ngetas ulit. Like rabat, it takes place on the bereaved family's section of the longhouse gallery. Beserara' means, literally, 'to sever', 'separate' or 'cut away'. What is cut away during the ritual is the branch of a plant stalk representing the deceased's 'plant-image'.

As with other rituals performed by Saribas shamans, the manang begins by first inviting his hosts to assist him in constructing a shrine called the pagar api ('fence of fire'), which serves as the focal point of his

20 In the past, the ulit period was much longer than it is today, particularly for prominent individuals, and mourning restrictions could be automatically lifted by carrying out a successful headhunting raid (see Sather 2003b: 201-2; Uchibori 1978: 114-21). During the colonial era, the length of ulit was reduced to a maximum of one month.

21 With the exception of widowed spouses, who are released from mourning by a separate ritual called muai tebalu, which is generally held well after ngetas ulit (see Sather 2003b: 204-5; Uchibori 1978: 121-26). 
performance. In the case of beserara' bungai, the distinctive feature of this shrine is a freshly cut plant stalk-most often bamboo or, alternatively, kayu kemali (Leea aculeata Bl.). This is fastened to an upright spear, the top of which is securely attached to a horizontal pole, just above head height, which is extended between house pillars perpendicular to the long axis of the house. The base of the spear is inserted into an earthenware jar, representing the rootstock of the bungai. The manang chooses one of the stalk's branches to represent the deceased's bungai and, to signify this, he attaches to it a bead or shell armlet. Over the end of the pole nearest to the family apartment he drapes a ritual cloth and either a bundle of undyed cotton thread or a white cotton cloth. This latter is called the kembai bungai and is said to draw to itself the straying souls of members of the bereaved family. At the conclusion of beserara bungai, the manang gathers together these souls and reinserts them in each owner's body. While the manang completes his preparations, women inside the bilik prepare offerings, consisting of various kinds of cultivated food plants, including fruit, plus popped rice, bamboo tubes of steamed rice and packets of glutinous rice. When the pagar api is completed, the women bring these offerings from the bilik and place them beside the earthenware jar representing the pugu' bungai.

Like rabat, the main feature of beserara' bungai is an extended narrative, which, in this case, concludes, like the sabak, with a journey to Sebayan. The opening stanzas are — again, like those of the sabak — set in the longhouse interior. Similarly, spirits of the ancestral dead have gathered outside at the base of the longhouse entry ladder. In this case, the leaders of the dead ask permission to sever the bungai and to take it, together with a share of the family's property, back with them to Sebayan. The manang, in replying, identifies himself with Selempandai, the god of creation. Not only does Selempandai fashion human bodies, but he also determines the length of each individual's lifespan. In performing the beserara' bungai, the manang assumes the role of Selempandai, as both a life-giver and an undoer of life- one who determines both the time of a person's birth and the time of his death (see Sather 2003a). Speaking as Selempandai, the manang informs the spirits that they must allow him not only to sever the bungai, but also to divide the family's property, including its stock of seeds and plant cuttings. The first half of the shaman's narrative describes this division. After announcing his intentions, the shaman briefly adopts the voice of the deceased. Here, and later in his chant, by giving voice to the deceased, 
the shaman in effect creates a dialogue between the living and the dead in which each acknowledges their grief in parting and describes their newfound responsibilities towards one another (Sather 2001: 336-37): $:^{22}$

Bedua' leman utai ditanam, anang kurang

Telesak tambak ubi enggi' aku dibai' aku mati

Pulai ngagai menua kami di Bukit Lebur Api

Ke menjadi, malam padam

Tang pagi menjadi mau' rerendang

Enggi' sida' ditanam ba' emperan tanah lelanji

Nyadi ubi madang jabang
Divide everything we cultivate, let neither receive less

My cuttings of cassava, I take with me to die

Returning to our country at Lebur Api Hill [in Sebayan] Lit by day, extinguished by night Comes morning, it [again] blazes brightly

Theirs, they [the living] plant on a fertile plain

Growing well in the cassava garden

Sapa babi berani ngenchuri ubi No wild boar dares to steal them

Laban sida' takut mati kena' tunang sendiri' leka senapang
For fear of being killed by a torrent of shotgun pellets

Depending on the ingenuity of the shaman, the list of cultivated crops (utai ditanam: 'planted things') is often extensive. On the occasion recorded here, ${ }^{23}$ in addition to cassava (ubiljabang), it consisted of sugar cane (tebu), Job's tears (nyeli'), mustard (chabi'), longbeans (retak), gourds (labu'), pumpkins (entekai), maize (jagung), hill rice (padi bukit), swamp rice (padi paya) and glutinous rice (padi pulut). It also included rubber gardens. Having received their equal share of these crops, the deceased, still speaking, now reciprocates with gifts of charms and medicines for the use of the living (Sather 2001: 352-53):

Uji sambut nuan enggau kukut Receive with the nails of your jari kanan right hand

Taring uting babi dupan enggau batu tanduk rusa' The rooting tusk of a pig and ngulam the petrified antler of a grazing sambar deer

22 Fox (2003) describes these dialogues as a distinctive feature of Austronesian funerary rituals.

23 On 28 October 1977 at Tanjong longhouse, Ulu Paku, Betong Division (see Sather 2001: 326). 
Enggau batu ai' ulih ngambi' di Together with a water-stone kaki kerangan charm found at the foot of a gravel bed

Ditambah enggau batu gumbang ke besegang ngalun kerangan

Tu' batu buah pauh laba berendam dikemeranka ikan bam

Kena' nuan nyeridika simpuli padi rutan

Ngambika belayan ia kedil jampat mansang
Add to it a petrified wave that dashed against the shingle

This is a petrified pauh laba fruit taken from beneath the sea where it was guarded by a whale Use it to tend your rutan rice

And your crops will be abundant and grow quickly

Beserara' bungai is essentially a rite of separation. The bereaved family, by dividing its property, particularly its stock of seeds and plant cuttings, erases its future material obligations towards the dead. Each is now provided with the necessary resources for a self-sufficient existence-the living in this world, the dead in Sebayan. This does not mean, of course, that the living will cease to make offerings to the dead or cease to expect benefits in return. With the exchange completed, the time has come to sever the bungai. Now transformed, the deceased again appears as a menacing spectre (Sather 2001: 360-61):

Ke begamal rigam-rigam ke tinggi jam-jam ...

Bemata mesai buah terung kanggan

Sintak seput iya munyi ai' surut matak langan ...

Nyawa iya seruran

dengam-dengam

Ngeli' ka sigi' mesai tempan
Now appearing huge and tall like a leafy tree ...

With eyeballs as big as eggplants

His breathing sounds like the ebbing rush of waves ...

His open mouth is forever eager to eat

His teeth are as large as anvils

As the shaman severs the branch representing the deceased's bungai, he reminds the deceased that, although they are now separated, he must not forget his descendants, particularly those who continue the bilik-family to which he belonged (Sather 2001: 368-69): 
Diatu' kitai nyau besarara' baka ira' tabu' tali

Bekejang meh kitai baka batang tampung titi

Tang nuan amang enda' nganjungka kami ubat ngasub kaya

Ngasuh raja, ngasuh gerai, ngasuh nyamai

Kena' kami nampung nerujung bilik penaik nuan ke di menua tu'
Now we are severed, separated like strands of a once braided cord

We are parted like logs once joined to form a footbridge But you must not neglect to send us charms that cause us to be rich

That bring us wealth, health and happiness

So that we who continue this bilik-family may prosper in this land

With the bungai now severed, the manang leads a party of mourners to the river where they cast the severed branch and offerings into the flowing water. Returning to the longhouse, the manang recovers the souls from the kembai bungai and restores them to the members of the bereaved family. He then returns to the pagar api to sing the final stanzas of his narrative. In them, his soul accompanies the spirits of the dead as they return to Sebayan. This time, the path they take is quite different from the one taken by the tukang sabak. It is more direct and has none of the barriers that the deceased's soul had to overcome on its initial journey to Sebayan.

\section{Recalling the spirits of the dead to the living world: The Gawai Antu}

The Gawai Antu focuses on the deceased as antu, hence its name. Its purpose, bards say, is diperantu ('to confirm the status [of the dead] as $a n t u^{\prime}$ ), thus making them fitting recipients of future prayers and offerings (see Umbat and Ensiring 2004: 5). In contrast to rabat and beserara' bungai, the Gawai Antu is a major community undertaking jointly sponsored by most, if not all, of the families making up the longhouse. It is also the most complex and costly. Performing it is an enormous economic investment, requiring years of planning and saving. Consequently, it is held at most once in a generation and is frequently deferred even longer. It is typically held only after a majority of families living in the longhouse have at least one deceased ancestor to be memorialised. By sponsoring it, a longhouse not only celebrates the achievements of its most recent generation of dead, but also demonstrates its own material success, thus advancing the status of its living members while, at the same time, validating that of their immediate ancestors. 
The Gawai Antu is often described by Saribas elders as a work of 'housebuilding' (berumah). This is signified at the beginning of the Gawai by the collection and fashioning of building materials and, at its conclusion, by the use of these materials to erect a wooden tomb hut (sungkup) over the grave of each of the newly memorialised dead. These tomb huts are described as rumah Sebayan - that is, as forming an 'afterworld longhouse'. Together, their construction symbolises the reconstitution of the longhouse dead as an independent longhouse community in which the newly deceased are now fully integrated members as a result of having been provided with a sungkup and the various other grave goods supplied to them during the Gawai. During the first stage of the Gawai, men thus prepare the materials for constructing the sungkup, while women cut bamboo, which they split and peel into weaving materials. ${ }^{24}$ During the next stage, the women, working inside the longhouse, weave these materials into special cylindrical baskets called garung, while men erect altars (rugan), which they attach to the main passageway pillars outside each family's apartment. From these pillars, family members hang items of remembrance that formerly belonged to the dead. Here, each evening and night during the Gawai, they set out food offerings in the rugan for the spirits of their family's dead.

After these preliminaries, the main Gawai opens at dawn with a ceremonial reception of guests, beginning with the specially invited men of prowess, who, taking the role of warriors, will drink one or the other of the two sacred rice wines served to them at the climax of the Gawai. Invited guests are called pengabang. The same term is also used to refer to the visiting spirits of the dead and gods of Sebayan who are invoked during the Gawai. In marked contrast to the informality that otherwise characterises longhouse life, the reception of visitors and the major ceremonial events that follow are carefully structured according to status, age and gender. As in all traditional Gawais, human hosts and guests assume the ceremonial roles of the spirit-heroes and gods, thus recreating in their seating and outward behaviour a numinous world of idealised precedence that characterises not only the realms of the gods and spiritheroes, but also those of the dead (Sather 1996: 98-99). Accordingly, a major task of each family head is to bedijir, 'to line up' or 'array in order', the visitors he seats at his family's section of the gallery. At major ritual

24 This work is done in a special area outside and separate from the longhouse called the taba' (Sather 2003b: 228). 
junctures before feasting, oratory or ritual processions, the tuai gawai, the elder chosen to be the principal festival leader, walks the length of the longhouse, notifying each family head to begin arranging his or her visitors in order of precedence. At other times, guests are free to move about and mingle informally with their kin and neighbours.

The welcoming of guests ends at sundown. After serving rice wine and an evening meal, the tuai gawai announces the beginning of the main ritual events. These open with processions by the guests around the longhouse gallery accompanied by welcoming music (ngalu petara) played for the gods and spirits of Sebayan whose presence the visiting guests enact. Next, the men of prowess, in ceremonial dress with drawn swords, dance along the gallery to 'clear' (ngerandang) and 'fence' (ngelalau) a pathway for the priest bards, who, once this is done, begin their invocation to recall the dead to the longhouse. From this point, the bards sing throughout the remainder of the night. As they sing, they move slowly forward in a continuously rotating motion, circumambulating, as they do, the entire longhouse gallery. Their movements are said to mimic those of the gods and spirits. ${ }^{25}$ Starting first in the tuai gawais apartment, the priest bards begin to sing of the coming of the gods and spirits, led by the principal gods and goddesses of Sebayan, who travel as married pairs-first, Raja Niram and his wife, Ini' Inan, and then their daughter Dara Rambai Geruda and her husband, Bujang Langgah Lenggan. ${ }^{26}$ They are followed by others and then by the spirits of the ancestors down through the most recent longhouse dead. The song relates that before the spirits of the dead take leave of Sebayan, they first pick charms to take for their Gawai hosts. These are described as fruits that hang from the branches of a miraculous palm tree called the ranyai. ${ }^{27}$ Described by some (Heppell et al. 2005: 26) as the Iban 'Tree of Life', the ranyai in fact grows not in this world, but in Sebayan, where its fruits can only be collected by the dead. Left behind by the spirits of the dead at the conclusion of the Gawai, they again take the form of charms meant for the use of the living.

25 Note that during the Gawai Antu, the spirits of the dead actually begin their nightly visits to the longhouse before this formal invocation takes place.

26 The latter is said to have taught the ancestors how to perform the Gawai Antu.

27 There is, in fact, considerable ambiguity about the ranyai (see Sather 2003b: 189), as it is also represented by a variety of shrines constructed on different ritual occasions. In one of its forms, also represented as a palm tree growing in Sebayan, its 'fruits' are trophy heads that only the bravest of the dead are able to collect. 
With the departure of the dead from Sebayan, the bards—still singingnow leave the tuai gawais apartment and enter the gallery. Here, as they move from one family's section to the next, they narrate the journey of the spirits as they travel through the cosmos to this world. As they sing, each bard carries a drinking bowl (jalung) in the palm of his right hand filled with rice wine. During this singing, the wine is said to change colour and acquire a magical potency so strong and lethal that only the brave may drink it. Shortly before dawn, as the invocation draws to a close, the dead arrive in the living world. In the words of the invocation, they are received with offerings, rice wine, cockfights and songs of praise. At this point, each bard, as he finishes singing, hands his bowl of ai jalung to an elderly woman, ${ }^{28}$ who sits facing one of the warriors assembled at the centre of the longhouse gallery. Here, she presents her cup, which the warrior receives and, after first clearing it with the tip of his sword, drinks down with a loud war cry. ${ }^{29}$

The next set of drinkers then destroys the rugan altars and throws them beneath the longhouse floor. For many, this is a poignant moment as it signals the impending departure of the dead. It is also a time of heightened danger. By inviting the dead directly into the public areas of the longhouse, the Gawai Antu temporarily dissolves the separation between the living and the dead that the singing of the sabak and the rite of beserara' bungai helped to create. ${ }^{30}$ As a consequence, the potential for calamity is enormous. Thus, while the Gawai enjoins a massive amount of feasting and drinking, the greater part of this occurs within a highly regulated setting, with publicly announced rules and carefully scheduled events, each signalled beforehand by the tuai gawai. Danger is thus managed through an explicit display of order.

28 This woman, in presenting the bowl to the warrior, is said to be acting on behalf or playing the role of the principal goddesses of Sebayan, Ini' Inan and Dara Rambia Geruda.

29 The role of these drinkers clearly highlights the continuing significance of male prowess in Saribas society. During the 1970s and 1980s, most of those who were asked to perform the part of warriors were policemen or soldiers in the Malaysian Army. When I first began fieldwork in Sarawak, there was still an active communist insurgency in which a number of younger Iban men were then fighting. Others had seen military action in the 1960s during Konfrontasi or, earlier yet, as trackers with the British Army during the Malayan Emergency. To be eligible to drink these ritual wines, a man should have either received a dream command or taken a human life in combat (bedengah) (Sather 1993: 101).

30 Note that, during these earlier rituals, the spirits of the dead must remain at the foot of the longhouse entry ladder. 
This display reaches its climax as contact with the dead intensifies, culminating with their arrival in the longhouse and the drinking of the sacred wines. After the first group of warriors has finished drinking the ai' jalung, and while the guests, both living and dead, are still present in the house, a final morning meal is served. For the living, this is characteristically a joyous feast, with heavy drinking. Typically, many who have had little sleep since the Gawai began now become intoxicated. The dramatic climax of the Gawai then follows: the drinking of the ai' garung. The hosts, each representing one of the families with dead to be memorialised, now form a series of processions to 'present the garung' (nganjung garung) to the most honoured group of warriors. The first is led by the tuai gawai, who carries his family's garung baskets, each containing a bamboo tube filled with rice wine. After a series of mock combats, the drinkers receive the wine and drink it down with a war cry. The ai garung is believed to be even more poisonous (bisa') than the ai' jalung. Some bards compare it to the ai' limban (or beru'), the fluids that flow from a decomposing corpse (Sather 2003b: 236). After drinking repeatedly, the warriors typically vomit.

As I have argued elsewhere (Sather 2012: 129-30), by drinking the sacred wines, these warriors 'consume' and so obliterate the last remaining traces of corpse-like materiality that still adhere to the dead. They thereby confirm their status, not only as antu, but also as potential petara, propelling them beyond the cycling of life and death to a future of immortality, as gods.

\section{Life as a journey of achievement}

As Fox asserts, in the indigenous religions of the Austronesian-speaking world, 'Creation' is characteristically seen as having 'produced myriad forms of being' - in short, 'a celebration of spiritual differentiation' - that typically express themselves in social terms in institutions of precedence and achievement (1987: 526). Thus, a common Austronesian image of this-worldly life is that of a metaphorical 'journey of achievement', in which '[l] iterally and spiritually, individuals are distinguished by their journeys. Rank, prowess, and the attainment of wealth can be taken as evident signs of individual enhancement in a life's odyssey' (Fox 1987: 526). 
This enhancement is typically validated at death, when each person's life journey comes to an end, so that mortuary rituals and feasting not only give recognition to the position each individual attains in life, but also translate 'this position into a similarly enhanced position in the afterlife' (Fox 1987: 526).

The Gawai Antu is very much a celebration of social and spiritual differentiation. A basic ideological premise of Saribas Iban society is that all individuals are essentially alike at birth (see Sather 1996). At the same time, however, Saribas society is also intensely competitive. Personal accomplishment is highly valued and is judged to be a sign of both individual merit and spiritual favour. The outcome of competition is differentiation-a process likened by the Iban to the art of weaving (Sather 1996: 74). Just as each cotton thread begins this process alike, in the end, after dyeing and weaving, it assumes a distinctive colour and place in a finished fabric. While some persons die at birth, or prematurely, before they have had a chance to gain social recognition, or suffer illfated deaths and so achieve no enduring place as ancestors, for the great majority, the Gawai Antu constitutes the principal occasion on which differences of achievement are publicly displayed and celebrated. Earlier, during rabat, the deceased's life history was recounted, his journey of achievement assessed and, on this basis, the amount of his adat pemati was fixed (Sather 1996: 100; Umbat and Ensiring 2004: 11). This amount is remembered and, during the Gawai Antu, determines the type of garung basket that is woven for him.

One basket is woven for each person who was old enough at the time of death to have been given a personal name (orang ke benama). Infants who die before being named receive only woven 'playthings' (ayam). In the Paku and Rimbas areas, seven different garung designs were recognised in the 1970s and 1980s, including one (called gelayan) to which everyone who bore a name-male, female, married or unmarried-was entitled. The other six denoted ascending levels of attainment. In the past, the highest-status designs were reserved for male war leaders, warriors and regional chiefs and, in the case of women, especially accomplished weavers. The special importance of each garung basket is that its design directly expresses the deceased's achieved status. Thus, the Iban say, it is a 'sign' (tanda) of the deceased in regard to his or her social and spiritual standing. 
As signs, the garung baskets, together with grave furnishings and the display of personal objects formerly belonging to the dead (today often including photographs), make it possible for those who participate in the Gawai to remember the now absent dead and so, briefly, to 'relive' their presence in this world. The provision of garung baskets and tomb huts is described as a means of 'remembering' (ngingat). In the course of being provisioned, the ancestral dead are feasted and invited into the public areas of the longhouse to mingle with the living. In this way, experiential distance is obviated and the living are made to feel that the dead are present among them, not anonymously, but intimately, as individual visitors. Among the dead, it is the most recent cohort, whose former presence is still freshest in the memories of their hosts, who are especially honoured and whose presence is the main object of the ritual. By the time the sponsoring community holds another Gawai Antu, its present hosts will have traded places with those who were children before, becoming the next generation of ancestral dead, dependent now upon a succeeding generation 'to remember' and so to assure them a place among the ancestral dead appropriate to their accomplishments in this life. By being remembered, the dead are at the same time empowered, emerging in the process as benevolent beings_ antu and future petaracapable for as long as they are remembered 'of returning benefits to the living' (Fox 1987: 526).

After the conclusion of the Gawai Antu, the garung baskets are carried to the cemetery where they are hung inside the tomb huts together with offerings and other objects meant for the use of the dead, including miniature farm baskets. The spirits of the dead are said to take these garung back with them to Sebayan, where they serve as signs of status. The ancestors, in departing, thus take the status they achieved in this world with them to the afterworld. In so doing, they leave their living descendants still journeying in this world free to embark upon statusenhancing journeys of their own devising (Sather 1996: 100-01). Death thus returns each new generation of descendants to a state of relative equality, while at the same time, it installs precedent and hierarchy as the organising principles of life in Sebayan. Finally, the construction of tomb huts reconstitutes the ancestral dead as a newly refurbished longhouse community, spatially differentiated and sufficiently independent of the living for its members to be safely invited to future Gawais as ritual visitors from beyond the human world. 


\section{Death as a source of differentiation}

While each person's life journey is seen as a potential source of social and spiritual differentiation, so, too, is death. The transition from life to death is thus perceived as having a variety of possible outcomes. For the majority, it results in the transit of their souls to Sebayan. But there are many exceptions. At death, shamans, for example, are buried with their heads oriented upriver ( $k e$ ulu), rather than downriver ( $k e$ ili') - the orientation of ordinary laypersons. This is because their souls, at death, are believed to travel not downriver to the Mandai River of the Dead, but upriver to a separate afterworld of their own located at the summit of Mount Rabung. ${ }^{31}$ From this abode, the spirits of deceased shamans continue to play an active role in this world, but one specifically associated with shamanism. During curing performances, living manang invite them to join them as spirit companions on their journeys into the unseen world. Some shamans also engage them as their individual spirit-helpers (yang). ${ }^{32}$ Although Iban shamanism is not, strictly speaking, an inherited calling, it tends to pass down along family lines, as does the transmission of healing charms, medicine boxes and the other ritual paraphernalia. Thus, most shamans maintain close ties to the spirits of their shamanic ancestors. In addition, the summit of Mount Rabung, where these spirits reside after death, is directly accessible to the upper-world home of the shamanic gods, Menjaya and his sister, Ini' Inda. Consequently, they are regularly called upon to accompany Menjaya and his sister whenever they are summoned to this world as ritual visitors. In addition, they are also responsible for tending the gardens where the bungai grow, which some shamans say are located on the slope of Mount Rabung (Sather 2001: 29-32; 2012: 123-24).

31 Like the Mandai River of the Dead, Mount Rabung is believed to have a visible counterpart in this world. Its identity, however, is less certain. Bukit Rabung is not visible from the Rimbas and Ulu Paku where I did my fieldwork but can be readily seen from higher elevations along the Sarawak-West Kalimantan border. It is easily identifiable by its distinctive profile, which resembles that of a gong, with a high rounded protuberance forming its summit (Sather 2001: 117). From its profile and the direction in which it appears, Mount Rabong would seem to be the same mountain that people in the upper Kapuas call Gunung Tilung, Tevilung or Tebilung, and which a number of other Dayak groups, like the Taman, regard as the abode of the dead (Bernard Sellato, Personal communication). According to Sellato, this mountain is identified on maps of West Kalimantan as Gunung Liang Sunan and is on the left bank of the Mandai River. In Iban, rabung means, literally, 'apex', 'summation', 'zenith' or 'highest point' (Sather 2001: 116). In Saribas chants, Bukit Rabung is described as being immediately beneath the 'zenith of the sky' (perabung langit).

32 Yang refers specifically to the spirit-helpers of ritual specialists-notably, shamans and priest bards. By contrast, tua' are personal guardian-spirits who assist those they take under their care by safeguarding their lives and aiding them in their quest for material wealth and renown. 
At death, the spirits of women who die in childbirth often become malevolent spirits known as antu kuklir and so remain for a brief time in this world to take revenge upon the living (Sather 1978). Others metamorphose at death directly into spirits, often malevolent ones such as antu gerasi (demon huntsmen), mythic beings such as nabau water serpents or animal spirits, usually dangerous ones like crocodiles or tigers. In the past, those who metamorphosed in this way were usually men of prowess, often war leaders or ritual specialists who engaged animal and demonic spirits as their spirit-helpers (Sather 2012: 39-40; Uchibori 2019: 229-30).

By contrast, the spirits of those who were especially successful in life often pay periodic visits to this world to protect their descendants or offer them assistance. In so doing, they sometimes assume the role of a personal guardian-spirit or tua' (Béguet 2012; Sather 2012: 137-40). In entering the visible world, tua' are typically 'concealed' (ngarung) in the visible form of animals. For this reason, guardian-spirits, in addition to tua', are also known as antu ngarung (literally, 'concealed spirits'). In Saribas, the spirits of dead ancestors who return to this world as tua' most often 'conceal' themselves as snakes, typically pythons (sawa) or, less often, cobras (tedung). Charles Hose, writing more than a century ago, referred to the animals in whose form the antu ngarung appear as 'totems', in that the animal spirit's protection frequently extended to a whole family or, over time, to a line of family descendants whose members, in return for the spirit's protection, refrained from killing, eating or injuring it (Hose and McDougall 1966: Vol. II, pp. 90-96). As Hose noted, however, not all antu ngarung are ancestors or even deceased humans.

Finally, there existed in the past an alternative form of ritual practice that was reserved for individuals of exceptional renown. Called ngelumbung ('entombment'), the corpse of the deceased was not buried in the earth, but instead was placed in a coffin (rarung), which was then set on a raised platform above ground and covered with a roof resembling a sungkup (Sather 2003b: 238-39; Uchibori 1978: 263-89, 1984). This whole structure was called a lumbung (or 'tomb'). Fluids were drained from the coffin and, after the fleshy parts of the corpse had decomposed, the bones were removed, cleaned, bundled together and placed inside a permanent container, either a jar or a hardwood coffin. In Saribas, almost all entombments occurred during the first generations of pioneer 
settlement, some 14-16 generations ago. ${ }^{33}$ Unlike the spirits of the ordinary dead, those who are entombed are believed to remain in this world. In this regard, their fate was modelled on that of the spirit-heroes and heroines (Orang Panggau). Thus, the purpose of entombment, for the most potent of the dead, was to bring about their immediate apotheosis. Rather than dispatching them, like the ordinary dead, on a journey to Sebayan, it instead served to retain their presence in the living world as powerful immortals-invisible, yet accessible to their descendants (Uchibori 1984: 30).

\section{Conclusion}

For the Iban, life and death are seen as interconnected journeys that unfold in different cosmic realms. Bridging these realms and connecting the living and the dead are additional journeys, including the ritually enacted journeys of the soul-guides, shamans and priest bards that make up, as we have seen, the principal events of the Saribas Iban funerary cycle.

The journey of life, or jalai idup, begins at birth and concludes at death. The self that undertakes this journey is an embodied self, which thereby differs from the disembodied postmortal self that undertakes the journey of death. Within the visible this-worldly realm in which this first journey occurs, it is the body, animated by the semengat, that is the conscious agent that initiates and executes a living person's actions (Sather 2018: 57-63). At death, the soul disengages from the body and journeys to Sebayan, where it is said to live on, merging in the minds of many with the antu Sebayan, which, after death, takes its place as the source of the deceased's continuing agency.

While still embodied, each person's life journey is seen as an arena of achievement. At death, an accounting is made of each individual's accomplishments and on this basis the amount is set of his or her adat pemati. This amount in turn determines the type of garung basket that is woven for the deceased during the Gawai Antu. At the conclusion of the Gawai, this basket is taken by the deceased's spirit, as it returns from this world to Sebayan, where, now fully incorporated into the society of the dead, it determines the deceased's status in the afterworld.

33 Uchibori, writing of the Skrang and Layar Iban in the mid-1970s, describes a number of more recent entombments (1984: 23-28). See also Sather (2012: 141). 
Death, coming between these two main journeys, represents both a transition and a source of potential transformation. With the departure of the soul, a new component of the self emerges, the antu Sebayan. Appearing initially as a spectre, the deceased's spirit, like his or her soul, journeys to Sebayan, where it gradually sheds its menacing form and becomes a generally benevolent spirit-that is, an antu Sebayan. There are exceptions, however. Death, like life, gives rise to a variety of new forms of being. Among them are the spirits of deceased shamans, who journey at death to a raised afterworld on the summit of Mount Rabung, where, as the spirit-companions of the living shamans, they assist the latter in their healing work. Others may metamorphose directly into nonhuman demonic or animal spirits or become beneficent guardian-spirits or $t u a$, while the most potent of the dead may be entombed and so, by avoiding burial, remain, like the Iban spirit heroes and heroines, active spirit agents in the living world. For the majority of the dead, usually within a generation of having settled in Sebayan, they are recalled by their living descendants to this world to complete their transformation. Here, reconstituted as a separate community, their status is confirmed not only as spirits, but also as potential future gods, capable of assisting the living as ritual visitors from beyond the human world.

Finally, the representation of these two journeys as journeys of regeneration rests upon an association of the temporal cycling of human life with that of plants. ${ }^{34}$ The most explicit expression of this association is with the 'plant-image' or bungai. As a component of the embodied self, the bungai directly mirrors, in the form of a living plant, the health and mortality of the embodied self of which it is an image. The conditions of its birth, growth and even its reproduction and death precisely replicate those of its human counterpart. At the same time, the bungai is also an image of regeneration and social renewal. By severing and removing the dead bungai during beserara' bungai, the shaman makes room on the parent rootstock for the appearance of new bungai. Thus, his action promotes continuity and reflects the capacity of the bungai to renew itself. At the same time, the bungai also symbolises the social dimensions of embodied selfhood. Individual bungai grow in family clumps in gardens representing

34 For a more general discussion of the use of 'botanic icons' in the Austronesian-speaking world as metaphors for human lifecycle processes, see Fox (1996). 
'longhouses of the souls'. Here, the rootstock (pugu' bungai) symbolises the capacity of these groups to replenish themselves and so persist beyond the lifetimes of their individual members.

A second way in which this analogy is represented is through an exchange of seeds and plant cuttings between the living and the dead, as each, through the husbandry of these planting materials, maintains a parallel, but separate productive system. Thus, during beserara' bungai, members of the bereaved family share with the spirits of the deceased their productive assets, including their food crops and stock of seeds and plant cuttings. In this way, the living provide the dead with the necessary resources to join them in promoting a parallel cycling of life through both the food crops they each cultivate and the successive generations of human cultivators, both living and dead, who subsist upon these crops.

Finally, at the end of the second and final of these journeys, the souls of the dead or, more accurately, the final material residue of these souls, are transformed into a watery mist that returns to this world, where it condenses and falls to earth. Here, in this form, it nourishes and is absorbed into each family's rice crop. Rice, in turn, as the staple food of the Iban, nourishes the families who cultivate it. And so, in this way, the final transformation of the souls becomes the ultimate metaphor of regeneration. Through rice, life-engendering potency is returned from one generation to the next and from Sebayan back to this world, thereby completing the ontological cycle of human life and death.

\section{References}

Béguet, Véronique. 2012. 'Iban petara as transformed ancestors.' In Pascal Couderc and Kenneth Sillander, eds, Ancestors in Borneo Societies: Death, transformation, and social immortality, pp. 243-77. Copenhagen: NIAS Press.

Blust, Robert. 2013. The Austronesian Languages. Rev. edn. Canberra: ANU AsiaPacific Linguistics.

Department of Statistics Malaysia. 2012. Population Distribution and Basic Demographic Characteristics Report 2010. Kuala Lumpur: Department of Statistics Malaysia.

Ensiring, Janang, Joanne Veydt Sutlive, Robert Menua Saleh and Vinson H. Sutlive, eds. 2016. A Comprehensive Iban-English Dictionary. Kuching: The Dayak Cultural Foundation in cooperation with The Tun Jugah Foundation. 
Firth, Raymond. 1967. 'The fate of the soul.' In Raymond Firth, Tikopia Ritual and Belief, pp. 330-53. Boston: Beacon Press.

Fox, James J. 1987. 'Southeast Asian religions: Insular cultures.' In Mircea Eliade, ed., The Encyclopedia of Religion. Volume 13, pp. 520-30. New York: Macmillan.

Fox, James J. 1996. 'The Austronesian botanic idiom.' In Tony Whitten and Jane Whitten, eds, Plants: Indonesian Heritage. Volume 4, pp. 66-67. Singapore: Archipelago Press.

Fox, James J. 2003. 'Admonitions of the ancestors: Giving voice to the deceased in Rotinese mortuary rituals.' In Peter J.M. Nas, Gerard A. Persoon and Rivke Jaffe, eds, Framing Indonesian Realities: Essays in symbolic anthropology in honour of Reimar Schefold, pp. 15-25. Leiden: KITLV Press.

Graham, Penelope. 1991. 'To follow the blood: The path of life in a domain of eastern Flores, Indonesia.' PhD dissertation, The Australian National University, Canberra.

Heppell, Michael, Limbang anak Melaka and Enyan anak Usen. 2005. Iban Art: Sexual selection and severed heads. Leiden: KIT Publishers.

Hertz, Robert. 1960. 'A contribution to the study of the collective representation of death.' In Robert Hertz, Death and the Right Hand, Rodney and Claudia Needham, trans, pp. 27-86. London: Cohen \& West.

Hose, Charles and William McDougall. 1966 [1912]. The Pagan Tribes of Borneo. 2 vols. London: Frank Cass \& Company.

Sather, Clifford. 1978. 'The malevolent koklir: Iban concepts of sexual peril and the dangers of childbirth.' Bijdragen tot de Taal-, Land, -en Volkenkunde 134: 310-55. doi.org/10.1163/22134379-90002590.

Sather, Clifford. 1993. 'Posts, hearths and thresholds: The Iban longhouse as a ritual structure.' In James J. Fox, ed., Inside Austronesian Houses: Perspectives on domestic designs for living, pp. 65-115. Canberra: Department of Anthropology, Research School of Pacific Studies, The Australian National University.

Sather, Clifford. 1996. “'All threads are white”: Iban egalitarianism reconsidered.' In James J. Fox and Clifford Sather, eds, Origins, Ancestry and Alliance, pp. 70-110. Canberra: Department of Anthropology, Research School of Pacific and Asian Studies, The Australian National University.

Sather, Clifford. 2001. Seeds of Play, Words of Power: An ethnographic study of Iban shamanic chants. Kuching: Tun Jugah Foundation and the Borneo Research Council. 
Sather, Clifford. 2003a. 'The shaman as preserver and undoer of life: The role of the shaman in Saribas Iban death rituals.' In Mihály Hoppál and Gábor Kósa, eds, Rediscovery of Shamanic Heritage, pp. 153-77. Budapest: Akadémiai Kiadó.

Sather, Clifford. 2003b. 'Transformations of self and community in Saribas Iban death rituals.' In William D. Wilder, ed., Journeys of the Soul: Anthropological studies of death, burial and reburial practices in Borneo, pp. 175-247. Phillips, ME: Borneo Research Council Monograph Series 7.

Sather, Clifford. 2004. 'The Iban.' In Ooi Keat Gin, ed., Southeast Asia: A historical encyclopedia. Volume 2, pp. 623-25. Santa Barbara, CA: ABC Clio Press.

Sather, Clifford. 2012. 'Recalling the dead, revering the ancestors: Multiple forms of ancestorship in Saribas Iban society.' In Pascal Couderc and Kenneth Sillander, eds, Ancestors in Borneo Societies: Death, transformation, and social immortality, pp. 114-52. Copenhagen: NIAS Press.

Sather, Clifford. 2018. 'A work of love: Awareness and expressions of emotion in a Borneo healing ritual.' In James J. Fox, ed., Expressions of Austronesian Thought and Emotions, pp. 47-79. Canberra: ANU Press. doi.org/10.22459/ EATE.04.2018.03.

Sutlive, Vinson H. 2012. Tears of Sorrow, Words of Hope: An ethnographic study of Iban death chants. 2 vols. Kuching: Tun Jugah Foundation and the Borneo Research Council.

Uchibori, Motomitsu. 1978. 'The leaving of this transient world: A study in Iban eschatology and mortuary practices.' PhD dissertation, Research School of Pacific Studies, The Australian National University, Canberra.

Uchibori, Motomitsu. 1984. 'The enshrinement of the dead among the Iban.' Sarawak Museum Journal 33: 15-32.

Uchibori, Motomitsu. 2019. 'Spirits as the others: From the Iban ethnography.' In Kawai Kaori, ed., Others: The evolution of human sociality, pp. 325-45. Kyoto and Melbourne: Kyoto University Press and Trans Pacific Press.

Umbat, Jantan and Janang anak Ensiring. 2004. Ripih Pengawa' Gawai Antu [Stages of the Gawai Antu]. [In Iban]. Kuching: The Tun Jugah Foundation.

Wadley, Reed L. 1999. 'Disrespecting the dead and the living: Iban Ancestor Worship and the violation of mourning taboos.' Journal of the Royal Anthropological Institute 5(4): 595-610. doi.org/10.2307/2661150. 
This text is taken from Austronesian Paths and Journeys, edited by James J. Fox, published 2021 by ANU Press, The Australian National University, Canberra, Australia.

doi.org/10.22459/APJ.2021.06 